\title{
SWOT Application in Marketing Strategy for Chicken Egg Shredded in UKM "Raja Abon Makmur Lestari" in Pangkalpinang City
}

\author{
Yulia $^{1, \#}$, Novyandra Ilham Bahtera ${ }^{1}$ Evahelda $^{1}$ \\ ${ }^{1}$ Department of Agribusiness, Faculty of Agriculture, Fisheries and Biology, Universitas Bangka Belitung, Bangka Belitung, Indonesia \\ e-mail: yuliaubb@gmail.com \\ ${ }^{\#}$ Corresponding Author \\ Whatsapp Number $\{+62-89663400094\}$
}

\section{ARTICLE HISTORY}

Received: 28 March 2019

Revised: 25 May 2019

Accepted: 10 July 2019

Copyright $\odot 2019$ Authors \& Published by IIES Independent. This is an open-access article distributed under the terms of the CC-BY-SA License.

\section{ABSTRACT}

This study was conducted based on not achieving the revenue target for the "Raja Abon Makmur Lestari" UKM in Pangkalpinang City. The purpose of this study was to analyze the position of SMEs in the IE matrix and formulate a marketing strategy for UKM "Raja Abon Makmur Lestari" in Pangkalpinang City. The research method used is case study. The number of samples used in this study were 55 samples, 5 samples from internal UKM "Raja Abon Makmur Lestari" and 50 samples from external UKM "Raja Abon Makmur Lestari". Methods of data collection using questionnaires and data analysis methods using IE analysis and SWOT analysis. The results showed that the position of "Raja Abon Makmur Lestari" UKM was in quadrant V. In this position SMEs could be managed with a strategy of maintaining and maintaining (hold and maintain), namely market penetration and development of abon telur products. The strategy formulation that must be carried out by UKM "Raja Abon Makmur Lestari" in Pangkalpinang City is to improve good and quality service to consumers, Maintain existing business places, Develop product delivery by having special vehicles, Maximize promotional activities by expanding market networks, Adjust product prices in accordance with the increase in raw materials, Increase innovation-new product innovations both in terms of taste, shape, Adjust product prices with the ability of consumers, and Have permanent outlets in developing the business.

Keywords: Marketing strategy; IE and SWOT

How to Cite: Yulia, Bahtera, N.,I \& Evahelda, (2019). SWOT Application in Marketing Strategy for Chicken Egg Shredded in UKM "Raja Abon Makmur Lestari" in Pangkalpinang City. International Journal of Advances in Social and Economics, 1 (2), 73-78.

\section{Introduction}

Economic development which currently relies on the industrial and trade sectors cannot be separated from the role of small and medium enterprises (SMEs). Small and medium enterprises are one of the leading driving forces in economic development (Soekartawi, 2005). The movement of the SME sector is vital to creating growth and employment. SMEs are quite flexible and can easily adapt to ups and downs and the direction of market demand.

Data from the Ministry of Cooperatives and Small and Medium Enterprises in 2014, there were around 57.8 million SMEs in Indonesia. In 2017 and in the next few years it is estimated that the number of SMEs will continue to grow. So far, SMEs have contributed to the Gross Domestic Product (PBD) of 57-60\% and the --- employment rate of around $97 \%$ of the total national workforce. Bangka Belitung Islands Province is one of the provinces in Indonesia that has the potential of wealth consisting of agriculture, fisheries, livestock and industry. With the existence of these potentials, the Bangka Belitung Islands Province is potential to develop economic growth in Indonesia.

According to the Department of Agriculture, Plantation and Animal Husbandry of Bangka Belitung Islands Province in 2015, Bangka Belitung Islands Province produced 582,784 kg of chicken eggs, where Air Kepala Tujuh Village, Gerunggang District, Pangkalpinang City became an important part in fulfilling the production of chicken eggs. This is a 
great opportunity for SMEs to process chicken egg raw materials into innovative products.

Eggs are livestock products that make the greatest contribution to achieving community nutrition adequacy (Saragih, 1998). From an egg, it is found that nutrition is quite perfect because it contains substances that are very good and easily digested, therefore eggs are a very good food for children who are growing and need protein and minerals in large quantities and are also recommended to be given to people who is sick to speed up the healing process.

Appropriate business strategy planning is an important matter and must be considered by SMEs to protect the business position of competitors (Fauzi, 2016; Octavianus, 2019). The number of competitors in the food business sector now causes SMEs to compete tightly so that the business can continue to provide services to loyal customers. SMEs must consistently maintain customer trust regarding the quality of service and execution of orders, on time is the key to success in facing competition in the business world (Michael P, 1994; Suryandharu, 2019). The company must provide the best service, consistent with quality, good outlet performers, and possess workers who are in accordance with their skills and competencies and assisted with modern and sophisticated equipment so that customers can trust the services provided by these SMEs.

In conducting marketing activities an SME has several objectives to be achieved, both short-term goals and long-term goals (Pearce et all, 2008; Mranani, 2019). In the short term it is usually to win the hearts of consumers, especially for newly launched products. Whereas in the long term it is carried out to maintain existing products in order to continue to exist. In general, understanding the marketing strategy concept needs to be introduced to an understanding of the concept of marketing strategies (Almasdi Y, 2013). In business, a good product must be followed by a good marketing step because the marketing strategy applied must be right on target (David, 2011).

There are several types of abon businesses in the UKM "Abon Makmur Lestari Raja". This indicates that food type business competition with different product innovations is quite a trend in the Bangka Belitung Islands Province, especially in Pangkalpinang City. Buyers of products that were originally only able to be enjoyed by upper class people, can now also be enjoyed by the lower middle class. "Raja Abon Makmur Lestari" UKM has a target in achieving business in abon ayam chicken products, therefore the business owner strives to fulfill the sales target of abon- telur products that have been set every month.

\section{Method}

This research was conducted at the "Raja Abon Makmur Lestari" UKM located on Jl. Date No. 54 Ex. Air Kepala Tujuh, Pangkalpinang City, Bangka Belitung Islands Province. This study uses a descriptive qualitative research method because the research problems describe the object under study in accordance with the actual conditions at the time of the study. The method of determining respondents is by using a purposive method and snowball sampling, which is determining the respondents with certain considerations which are initially small in number, then increasing according to the need to get complete research data. To get information about the "Raja Abon Makmur Lestari" UKM in Pangkalpinang City, the writer conducted an interview with Ms. Parminah and 4 employees, as the daily executor at the UKM "Abon Makmur Lestari Raja". The informant for this initial study only interviewed five informants.

Furthermore, from the information obtained, the author will conduct interviews with consumers who are still shredded chicken eggs so that information can be explored more deeply so that complete data can be obtained for analysis. It does not rule out the possibility that informants in this study will increase again for information development. This research was conducted in August-October 2018. The number of respondents was 55 respondents.

\section{Identification of External and Internal Factors}

The first step that must be done is to identify internal factors both strengths and weaknesses as well as external identification by registering the opportunities and threats they have. Internal and external factors that have been identified, then asked for input from respondents who are believed to master the problem to do the reduction, addition and sharpening of these factors (Tari, 2015).

To anticipate the existence of other important factors that have not yet entered, then the questionnaire is given an empty place at the bottom, so that respondents can add other factors that are considered relevant to the existing problems.

\section{Weighting Technique}

Determination of weight on the analysis of external and internal factors is done by asking questions to the expert/strategist using central tendencys. The method is used to provide respondents with an assessment of 
each of the strategic factors carried out by giving a sign $(V)$ at the level of importance (1 to 3 ) that is most appropriate according to the respondent.

Determination of weight is the view of each respondent on strategic factors that have been reviewed from the whole element. The alternatives for weighting the strategic factors available for this questionnaire are:

$1=$ Not important

$2=$ Important

$3=$ Very important

The weight given to each factor is in the range of 0.0 (not important) to 1.0 (very important). Factors that are considered to have the greatest influence on company performance are given the highest weight, regardless of whether these factors are key strengths and weaknesses as well as opportunities and threats. The total number of weights given to each factor must be equal to 1.0. The weight value of each factor is obtained by dividing the number of the average value of each variable towards the total average value of all variables using the following formula:

$\mathrm{ai}=\mathrm{Xi} /\left(\Sigma_{-}(\mathrm{i}=1)^{\mathrm{i}} . \mathrm{Xi}\right)$

Information :

$\mathrm{ai}=$ Value of weight factor $\mathrm{i}$

$\mathrm{Xi}=\mathrm{i}$-factor average value

$\mathrm{i}=1,2, \ldots ., \mathrm{n}$

\section{Rating Determination}

According to (Rangkuti, 2006), rating (ranking) describes how much effective the company's current strategy is in responding to existing strategic factors.

\section{Multiplication of Weight and Ranking}

The next step, the weighting value is compiled with a rating on each factor and the weighted value of each factor is then summed to obtain the organization's weighted total value.

The total weighted value in the IFE and EFE matrices will be in the range of 1.0 (lowest) to 4.0 (highest), with an average value of 2.5 . The higher the weighted total value of the company in the IFE and EFE matrix indicates the company responds to strengths and weaknesses (internal factors) or opportunities and threats (external factors) very well, and vice versa.

\section{Internal-External Matrix (IE)}

The IE matrix is based on two key dimensions: the total IFE values are weighted on the $\mathrm{x}$-axis and the total EFE values are weighted on the y-axis. The IE matrix can be divided into three main parts which have different strategic impacts. First, divisions that enter cells I, II, IV can be called growing and building.

Intensive strategies (market penetration, market development, or product development) or integrative (backward integration, forward integration, horizontal integration) may be most appropriate for these divisions. Second, the divisions included in cells III, V, or VII, are best managed by a strategy of maintaining and maintaining

Market penetration and product development strategies are two strategies commonly used for these types of divisions. Third, divisions included in cells VI, VIII, or IX, are best managed with a harvest or divestment strategy.

\section{Strengths-Weaknesses-Opportunities-Threats (SWOT) Matrix}

The SWOT matrix is based on the assumption that effective strategies will maximize strengths and opportunities and minimize/avoid weaknesses and threats. The combination of external and internal factors in the SWOT matrix, namely strengthopportunity (S-O) strategy, opportunity-weakness strategy (W-O), weakness-threat strategy (W-T) and strength-threat strategy (S-T). Analysis of the SWOT matrix will produce several alternative strategies that the company can choose from in developing its business (Table 1). 
Table 1. Analysis of the SWOT Matrix

\begin{tabular}{|c|c|c|}
\hline & $\begin{array}{c}\text { Power } \\
(\text { Strengths }-S) \\
\text { List of strengths from internal factors }\end{array}$ & $\begin{array}{c}\text { Weakness } \\
(\text { Weaknesses }-W) \\
\text { List of weaknesses from internal factors }\end{array}$ \\
\hline $\begin{array}{c}\text { Opportunity } \\
\text { (Opportunities - O) } \\
\text { List of opportunities from external } \\
\text { factors }\end{array}$ & $\begin{array}{c}\text { SO strategy } \\
\text { Use strength to take advantage of opportunities }\end{array}$ & $\begin{array}{c}\text { WO Strategy } \\
\text { Overcome weaknesses by taking advantage } \\
\text { of opportunities }\end{array}$ \\
\hline $\begin{array}{c}\text { Threat } \\
(\text { Threats }-T) \\
\text { List of threats from external factors }\end{array}$ & $\begin{array}{l}\text { ST strategy } \\
\text { Use the power you have to avoid threats }\end{array}$ & $\begin{array}{c}\text { WT Strategy } \\
\text { Minimize weaknesses and avoid threats }\end{array}$ \\
\hline
\end{tabular}

\section{Figure 1. SWOT Matrix}

Source: David, 2011

\section{Results and Discussion}

\section{Internal Strategy Factors}

Based on the interviews and input from respondents obtained from several strategic factors that become strengths and weaknesses in the Implementation of Chicken Egg Shredded Marketing Strategy in UKM "Raja Abon Makmur Lestari" of Pangkalpinang City namely for the strength factor is good service to consumers, safe and comfortable place of business , using sophisticated production equipment, having a good workforce organizational structure, while for the weakness factor is a poor tracking system, a less than optimal promotion, a less strategic business place, no fixed outlets.

External Strategy Factor
Based on interviews and input from respondents obtained from several strategic factors that become opportunities and threats in the Implementation of Chicken Egg Shredded Marketing Strategy in UKM "Raja Abon Makmur Lestari" in Pangkalpinang City, namely for opportunity factors are changes in consumer lifestyles, business locations close to provincial cities, the main job of the owner, the consumer wants fast/practical, while for the threat factor is the presence of competing products, the increase in raw material costs, the influence of fluctuating raw material prices.

\section{Evaluation of Strategic Factors}

Internal Factor Evaluation

Table 1. Internal Factor Evaluation Matrix

\begin{tabular}{lccc}
\hline \multicolumn{1}{c}{ Internal factors } & Weight & Rating & Average Total Score \\
\hline Power & & & 0.525 \\
Good service to consumers & 0.175 & 3 & 0.408 \\
A safe and comfortable business place & 0.102 & 4 & 0.324 \\
Sophisticated production equipment & 0.180 & 3 & 0.720 \\
Good work organization structure & 0.180 & 4 & 1.977 \\
\hline Total & 0.637 & & 0.086 \\
\hline Weakness & & 1 & 0.102 \\
Poor tracking system & 0.086 & 1 & 0.070 \\
Promotions that are not maximal & 0.102 & 1 & 0.210 \\
The place of business is less strategic & 0.070 & 2 & 0.468 \\
Don't have fixed outlets & 0.105 & & 2.445 \\
\hline \multicolumn{1}{c}{ Total } & 0.363 & & \\
\hline \multicolumn{1}{c}{ Total } & 1.000 & & \\
\hline
\end{tabular}

Evaluation of External Factors

Table 2. External Factor Evaluation Matrix

\begin{tabular}{|c|c|c|c|}
\hline External factors & Weight & Rating & Average total score \\
\hline \multicolumn{4}{|l|}{ Opportunity } \\
\hline Changes in consumer lifestyles & 0.140 & 3 & 0.420 \\
\hline Business location near the provincial city & 0.160 & 3 & 0.480 \\
\hline The main job of the owner & 0.120 & 3 & 0.360 \\
\hline Consumers want fast / practical & 0.111 & 2 & 0.222 \\
\hline Total & 0.531 & & 1.482 \\
\hline \multicolumn{4}{|l|}{ Threat } \\
\hline presence of competing products & 0.179 & 3 & 0.537 \\
\hline
\end{tabular}




\begin{tabular}{cccc}
\hline & & 2 & 0.300 \\
increase in raw material costs & 0.150 & 4 & 0.560 \\
\hline the effect of fluctuating raw material prices & 0.140 & 1.397 \\
\hline Total & $\mathbf{0 . 4 6 9}$ & $\mathbf{2 . 8 7 9}$ \\
\hline Total & 1.000 & \\
\hline
\end{tabular}

In each of the total scores of internal and external factors can be mapped in the matrix, the position of SMEs is located in quadrant V. In this position SMEs can be managed with a strategy of maintaining and maintaining, namely market penetration and development of abon ayam products which are the two most used strategies in this type of strategy. The position of UKM Raja Abon Makmur Lestari relative to abon chicken processing can be seen in Figure 2:

Total Weighted Average IFE

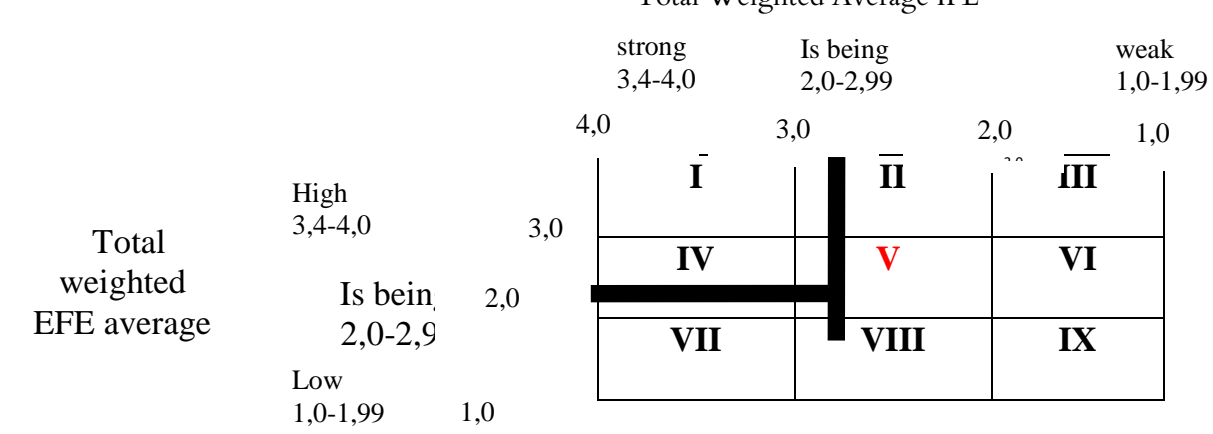

Figure 2. Position of UKM "Raja Abon Makmur Lestari"

Determination of Alternative Marketing Strategies for SMEs "Prosperous King of Sustainable Prosperity"

Alternative strategies that will be recommended in marketing abon Ayam Telur products by creating a SWOT matrix that illustrates clearly how the opportunities and threats faced by SMEs are combined with the strengths and weaknesses of SMEs. SWOT analysis is the formulation of conventional strategies that underlie a form of strategy tailored to the conditions in the field (Tresnaprihandini, 2006). In the formulation of the strategy with the SWOT matrix produces several alternative strategies as shown in Figure 3.

\begin{tabular}{|c|c|c|}
\hline & $\begin{array}{c}\text { STRENGTH (S) } \\
\text { S1 Good service to consumers } \\
\text { S2 A safe and comfortable place of business } \\
\text { S3 Advanced production equipment } \\
\text { S4 Good work organization structure }\end{array}$ & $\begin{array}{c}\text { WEAKNESS (W) } \\
\text { W1 Poor tracking system } \\
\text { W2 Promotions that are less than optimal } \\
\text { W3 The place of business is less strategic } \\
\text { W4 does not have fixed outlets }\end{array}$ \\
\hline $\begin{array}{c}\text { OPPORTUNITIES (O) } \\
\text { O1 Consumer lifestyle } \\
\text { changes } \\
\text { O2 Business location close to } \\
\text { the provincial city } \\
\text { O3 The main job of the } \\
\text { owner } \\
\text { O4 Consumers want fast / } \\
\text { practical }\end{array}$ & $\begin{array}{l}\text { S-O STRATEGY } \\
\text { 1. Improving good and quality service to } \\
\text { consumers (S1, O1, O4) } \\
\text { 2. Maintaining an existing place of business (S2, } \\
\text { O2) }\end{array}$ & $\begin{array}{c}\text { W-O STRATEGY } \\
\text { 1. Developing product shipments by having } \\
\text { special vehicles, such as motorcycles (W1, O4) } \\
\text { 2. Maximizing promotional activities by } \\
\text { expanding the market network (W2, W4, O2) }\end{array}$ \\
\hline $\begin{array}{c}\text { THREATS }(\mathrm{T}) \\
\text { T1 the existence of } \\
\text { competing products } \\
\text { T2 increases in raw material } \\
\text { costs } \\
\text { T3 influences fluctuating raw } \\
\text { material prices }\end{array}$ & $\begin{array}{c}\text { S-T STRATEGY } \\
\text { Adjust product prices according to increases in raw } \\
\text { materials }(\mathrm{S} 3, \mathrm{~T} 2, \mathrm{~T} 3) \\
\text { Increasing innovation-new product innovations } \\
\text { both in terms of taste, form }(\mathrm{S} 1, \mathrm{~T} 1)\end{array}$ & $\begin{array}{c}\text { W-T STRATEGY } \\
\text { Adjust product prices with consumer capabilities } \\
\text { (W1, T3) } \\
\text { Having fixed outlets in developing businesses } \\
\text { (W4, T1) }\end{array}$ \\
\hline
\end{tabular}




\section{Conclusions and Recommendations}

\section{Conclusion}

Based on the results of the research that has been done, it can be concluded as follows: 1) the position of "Raja Abon Makmur Lestari" UKM is in the V quadrant, namely, hold and maintain strategy, which means market penetration and development of abon eggs in overcoming competitive market developments in order to expand the marketing network. 2) The formulation of marketing strategies that must be carried out by UKM "Raja Abon Makmur Lestari" in Pangkalpinang City is to improve good and quality services to consumers, Maintain existing business places, develop product delivery by having special vehicles, maximize promotion activities by expanding market network, adjusting product prices according to the increase in raw materials, increasing innovation-new product innovations both in terms of taste, shape, adjusting product prices with the ability of consumers, and having fixed outlets in developing the business of abon chicken egg products.

\section{Recommendations}

- The UKM "Raja Abon Makmur Lestari" should routinely increase product variations, given the opportunity for SMEs according to consumer demand for the sale of abon ayam ayam products.

- SMEs "Raja Abon Makmur Lestari" are expected to be able to improve the quality of service so that there are no complaints from consumers so that consumers are not affected by competing products.

\section{References}

David FR. (2011). Strategic Management: Concepts and Cases. South Carolina (FR). Prentice Hall.

Fauzi D. (2016). Strategi Pengembangan Agribisnis Kentang Merah di Kabupaten Solok. Jurnal Agraris. 2(1): 88-96.

Mranani, N., A.,\& Lastianti, S., D. (2019). Analysis of The Effect of Experiential Marketing And Community Reference on Purchase Decisions (Study In Surabaya Brain Coffee). International Journal of Advances in Social and Economics, 1 (1), 36-44.

Octavianus, S. (2019). The Cultivation of Indonesia's Education Financing Policy in Disruption Era. International Journal of Advances in Social and Economics, 1(1), 16-21.
Pearce JA, Robinson. (2008). Manajemen Strategik: Formulasi, Implementasi dan Pengendalian, Jilid I. Edisi 10. Jakarta (ID): Bina Rupa Aksara

Porter, Michael E. (1994). Keunggulan Bersaing, Menciptakan dan Mempertahankan Kinerja Unggul. Binarupa Aksara. Jakarta.

Rangkuti, F. (2006). Analisis SWOT Teknik Membedah Kasus Bisnis. Jakarta: PT. Gramedia Pustaka Utama.

Saragih B. (1998). Agribisnis Berbasis Peternakan, Kumpulan Pemikiran. Bogor (ID): Pusat Studi Pembangunan Lembaga Penelitian Institut Pertanian Bogor.

Soekartawi. (2005). Pengantar Agroindustri. Raja Grafindo Persada. Jakarta.

Suryandharu, T., Sanusi, A., \& Harsono, H. (2019). The Influence of The Motivation, Leadership and Social Networking for the Formation of Social Entrepreneurship. International Journal of Advances in Social and Economics, 1(1), 6-15.

Tari, M. (2015). Strategi Pengembangan Usaha Ekspor Udang Beku PT Timur Jaya Cold Unit IV Muara Baru Jakarta Utara. Jurnal Manajemen dan Agribisnis. 10(2): 109-116

Tresnapri, Handini. (2006). Formulasi Strategi Pengembangan Usaha Kerupuk Udang dan Ikan pada Perusahaan CANDRAMAWA di Kabupaten Indramayu. Skripsi Jurusan Sosial Ekonomi Pertanian. Fakultas Pertanian. Institut Pertanian Bogor.

Yahza, Almasdi. (2013). Bahan Kuliah Manajemen Agribisnis: Perbedaan manajemen agribisnis dengan manajemen lainnya. 